\title{
THE APPLICATION OF GUIDED DISCOVERY LEARNING MODEL TO IMPROVE STUDENTS' CRITICAL THINGKING ABILITY AT THE EIGHTH GRADE STUDENTS' OF MTS AL-HUDA PEKANBARU
}

\author{
Arif Fadillah $^{* 1)}$, Yennita $^{2)}$, Muhammad Sahal ${ }^{3)}$ \\ ${ }^{1,2,3)}$ Physics Education, University of Riau \\ e-mail: arif fadillah47@yahoo.com \\ yennitacaca@yahoo.com \\ mhmmdsahal18@gmail.com
}

\begin{abstract}
Critical thinking is one of the high-level thinking stages that can be interpreted as a process of thinking precisely, directed, reasoned, and reflective in decision-making that can be trusted. This study was aimed to determine the improvement of critical thinking skills toward Guided Discovery Learning model of grade VIII students at MTs Al-Huda Pekanbaru on light material. The type of research used was experimental research. Descriptive analysis was used to analyze the data. This analysis gave the description about influence of Guided Discovery Learning model toward student's critical thinking ability. The subjects of this study were 58 students. The data was collected based on critical thinking skill's test result which consisted of 15 essay questions for 5 indicators after Guided Discovery Learning model was applied on experiment class and conventional model on control class. Mean score of sudents' critical thinking ability on experiment class was 78.45 which was in a high category and average score of students' critical thinking skill on control class was 70.52 which was in low category. Based on the result of students' critical thinking skill, it can be concluded that there was an improvement of critical thinking ability after guided discovery learning model was applied by $11.24 \%$ compared to conventional learning model.
\end{abstract}

Keywords: critical thinking, light, guided discovery learning.

\section{PENERAPAN MODEL GUIDED DISCOVERY LEARNING UNTUK MENINGKATKAN KEMAMPUAN BERPIKIR KRITIS SISWA KELAS VIII MTs AL-HUDA PEKANBARU}

\author{
Arif Fadillah $^{* 1)}$, Yennita ${ }^{2)}$, Muhammad Sahal ${ }^{3)}$ \\ ${ }^{1,2,3)}$ Pendidikan Fisika, Universitas Riau
}

\begin{abstract}
Abstrak
Berpikir kritis merupakan salah satu tahapan berpikir tingkat tinggi yang dapat diartikan sebagai proses berpikir secara tepat, terarah, beralasan, dan reflektif dalam pengambilan keputusan yang dapat dipercaya. Penelitian ini bertujuan untuk mengetahui peningkatan kemampuan berpikir kritis terhadap model pembelajaran Guided Discovery Learning siswa kelas VIII MTs Al-Huda Pekanbaru pada materi cahaya. Jenis penelitian yang dilakukan adalah kuasi eksperimen. Analisis data hasil penelitian ini adalah analisis deskriptif untuk memberikan gambaran tentang pengaruh model Guided Discovery Learning terhadap kemampuan berpikir kritis siswa. Subjek penelitian sebanyak 58 siswa. Pengumpulan data penelitian ini berdasarkan hasil tes keterampilan berpikir kritis berupa soal essay berjumlah 15 soal untuk 5 indikator
\end{abstract}


setelah diterapkan model Guided Discovery Learning pada kelas eksperimen dan model konvensional pada kontrol. Hasil penelitian menunjukkan bahwa rata-rata kemampuan berpikir kritis siswa kelas eksperiment setelah diterapkannya model pembelajaran guided discovery learning lebih tinggi dibanding kelas kontrol yang diterapkan model pembelajaran konvensional. Rata-rata skor keterampilanberpikir kritis siswa kelas eksperimen adalah 78.45 dengan kategori tinggi dan rata-rata skor keterampilan berpikir kritis siswa kelas kontrol adalah 70.52 dengan kategori rendah. Berdasarkan hasil analisis data keterampilan berfikir kritis siswa, maka dapat disimpulkan bahwa terdapat peningkatan kemampuan berpikir kritis setelah diterapkan model pembelajaran guided discovery learning sebesar $11.24 \%$ dibanding dengan model pembelajaran konvensional.

Kata kunci: berpikir kritis, cahaya, guided discovery learning.

\section{Pendahuluan}

Pendidikan merupakan suatu kegiatan yang sistematis dan sistemik terarah kepada terbentuknya kepribadian peserta didik. Pendidikan menurut UU No. 20 Tahun 2003 adalah usaha sadar dan terencana untuk mewujudkan suasana belajar dan proses pembelajaran agar peserta didik secara aktif mengembangkan potensi dirinya untuk memiliki kekuatan spritual keagamaan, pengendalian diri, kepribadian, kecerdasan, akhlak mulia, serta keterampilan yang diperlukann dirinya, masyarakat, bangsa, dan negara (Permendikbud, 2016). Suyono dan Hariyanto (2011) mengungkapkan bahwa salah satu tujuan pendidikan adalah untuk membentuk siswa yang memiliki kecakapan hidup (life skill) yang baik. Secara umum kecakapan hidup diklasifikasikan menjadi empat jenis, yaitu: (a) kecakapan personal (personal skill) yang mencangkup kecakapan mengenal diri (self awareness) dan kecakapan berfikir (thinking skill), (b) kecakapan social (social skill), (c) kecakapan akademik (academic skill), dan (d) kecakapan vokasional (vocational skill).

Seiring dengan perkembangan teknologi informasi yang begitu pesat, kompetensi yang dimiliki siswa tidak terbatas pada keterampilan proses, melainkan perlu memiliki kemampuan berpikir dan bertindak untuk menerima, memilih, dan mengolah informasi. Kemampuan berpikir yang perlu dikembangkan adalah kemampuan berpikir kritis. Kemampuan berpikir kritis merupakan salah satu modal dasar atau modal intelektual yang penting bagi setiap orang dan merupakan bagian yang paling mendasar dari kematangan berpikir manusia (Kowiyah, 2012). Model pembelajaran yang dapat memfasilitasi kemampuan berpikir kritis dan sistematis siswa perlu dikembangkan tidak hanya untuk beberapa mata pelajaran melainkan untuk seluruh mata pelajaran, tidak terkecuali mata pelajaran fisika. Fisika bukan sebagai ilmu hafalan rumus, tetapi merupakan proses penemuan. Oleh sebab itu, proses pembelajaran fisika seharusnya menekankan pada pemberian pengalaman langsung kepada siswa agar dapat mengembangkan kemampuan berpikir kritis yang dimiliki siswa. Keterampilan berfikir kritis yang perlu dikuasai individu mencakup menganalisis, mengkritisi, memutuskan, mengevaluasi, membandingkan, dan menaksir (Wowo, 2012). Berdasarkan hasil pengamatan penulis melalui pemberian instrumen soal berupa 10 soal objektif tentang konsep dasar fisika yang mengukur kemampuan berpikir kritis siswa. Hasil pengamatan menunjukkan rata-rata siswa hanya mampu menjawab 3-4 soal dengan benar atau 30\% - 40\% dari jumlah soal yang tersedia. Sehingga hal ini dapat dijadikan sebagai landasan yang memperkuat observasi dan wawancara penulis bahwa tingkat keterampilan berpikir siswa khususnya dalam pembelajaran ipa masih tergolong rendah. Untuk memecahkan permasalahan pembelajaran yang demikian perlu dilakukan upaya antara lain berupa perbaikan strategi pembelajaran yaitu mengubah model pembelajaran yang dapat memfasilitasi terjadinya komunikasi antara siswa dengan siswa dan guru dengan siswa, sehingga mampu menumbuhkan berpikir kritis siswa.

Salah satu model pembelajaran yang dapat digunakan sesuai dengan naluri manusia untuk selalu berusaha mencari, menemukan, dan memberikan tanggapan adalah dengan 
menggunakan model pembelajaran penemuan terbimbing (guided discovery learning) (Rusman, 2012). Oleh sebab itu penelitian tentang penerapan model pembelajaran fisika guided discovery learning untuk meningkatkan kemampuan berpikir kritis siswa perlu dilakukan.

\section{Bahan dan Metode}

Penelitian ini dilakukan MTs Al-Huda Pekanbaru pada bulan Maret - Juni 2018. Jenis penelitian yang dilakukan adalah kuasi eksperimen. Rancangan yang digunakan pada penelitian ini adalah Intact Group Comparison (Setyosari, 2010). Rancangan penelitian ini dapat dilihat pada Gambar 1.

\begin{tabular}{|lll|}
\hline Kelas Eksperimen & $\mathrm{X}$ & $\mathrm{O}_{1}$ \\
Kelas Kontrol & & $\mathrm{O}_{2}$ \\
\hline
\end{tabular}

Gambar 1. Rancangan penelitian.

Dimana :

$\mathrm{O}_{1}=$ Skor posttest kelas eksperimen

$\mathrm{O}_{2}=$ Skor posttest kelas kontrol

$\mathrm{X}=$ Perlakuan dengan penerapan model pembelajaran guided discovery learning

Analisis data dilakukan secara deskriptif. Hasil analisis data secara deskriptif ditunjukkan dalam bentuk tingkat keterampilan berpikir kritis seperti pada Tabel 1 .

Tabel 1. Kategori tingkat keterampilan berpikir kritis siswa

\begin{tabular}{|c|c|}
\hline SKBKS & Kategori \\
\hline $85.01 \leq \mathrm{SKBKS} \leq 100$ & Sangat Tinggi \\
\hline $75.01 \leq \mathrm{SKBKS} \leq 85$ & Tinggi \\
\hline $65.01 \leq \mathrm{SKBKS} \leq 75$ & Rendah \\
\hline$\leq 65$ & Sangat Rendah \\
\hline
\end{tabular}

Untuk melihat peningkatan keterampilan berpikir kritis dapat dilihat pada kategori peningkatan keterampilan berpikir ritis seperti pada Tabel 2.
Tabel 2. Kategori Peningkatan Keterampilan Berpikir Kritis

\begin{tabular}{cc}
\hline Kriteria & Kategori \\
$\Delta X$ & \\
\hline$\Delta X>0$ & Terjadi peningkatan \\
$\Delta X=0$ & Tidak Terjadi peningkatan \\
$\Delta X<0$ & Terjadi penurunan \\
\hline
\end{tabular}

\section{Hasil dan Pembahasan}

Soal tes kemampuan berpikir kritis siswa diujikan menggunakan 15 butir soal essay yang dikembangkan berdasarkan 5 indikator berpikir kritis yaitu kemampuan interpretasi, analisis, evaluasi, kesimpulan, dan kemampuan menjelaskan. Berikut data hasil tes keterampilan berpikir kritis sebagaimana terlihat pada Tabel 3 .

Tabel 3.Hasil Tes Keterampilan Berpikir Kritis

\begin{tabular}{|c|c|c|c|c|c|}
\hline \multirow{2}{*}{ No } & \multirow{2}{*}{$\begin{array}{l}\text { Indikator } \\
\text { Keterampilan } \\
\text { Berpikir } \\
\text { kritis } \\
\end{array}$} & \multicolumn{2}{|c|}{ Kelas Eksperimen } & \multicolumn{2}{|c|}{ Kelas Kontrol } \\
\hline & & Skor & Kategori & Skor & Kategori \\
\hline 1 & Interpretasi & 87,36 & Sangat Tinggi & 79,60 & Tinggi \\
\hline 2 & Analisis & 73,85 & Rendah & 67,24 & Rendah \\
\hline 3 & Evaluasi & 74,43 & Rendah & 63,51 & Sangat Rendah \\
\hline 4 & Kesimpulan & 80,75 & Tinggi & 73,56 & Rendah \\
\hline \multirow[t]{2}{*}{5} & Penjelasan & 75,86 & Tinggi & 68,68 & Rendah \\
\hline & Rata-Rata & 78,45 & Tinggi & 70,52 & Rendah \\
\hline
\end{tabular}

Tabel 3 menunjukkan bahwa rata-rata kemampuan berpikir kritis siswa kelas eksperiment setelah diterapkannya model pembelajaran guided discovery learning lebih tinggi dibanding kelas kontrol yang diterapkan model pembelajaran konvensional. Tabel 3 juga menunjukkan bahwa rata-rata kemampuan berpikir kritis siswa kelas eksperiment setelah diterapkannya model pembelajaran guided discovery learning lebih tinggi dibanding kelas kontrol yang diterapkan model pembelajaran konvensional. Hal ini sesuai dengan penelitian yang telah dilakukan oleh Candra Eko Purwanto, et al. (2012) dengan hasil yang didapat adalah pembelajaran guided discovery dapat meningkatkan kemampuan berpikir kritis siswa. Penelitian yang dilakukan oleh Angga Riantino dan Wasis (2014) juga membuktikan bahwa pembelajaran dengan guided discovery dapat meningkatkan keterampilan berpikir kritis 
siswa. Hasil yang didapat bahwa model guided discovery dapat meningkatkan berpikir kritis pada siswa pada setiap indikator dimana indikator yang digunakan adalah domain kognitif penerapan (C3), Analisis (C4), Sintesis (C5), dan Evaluasi (C6). Tingkat keterampilan berpikir kritis siswa pada setiap indikator dapat di analisis sebagai berikut.

\section{Keterampilan interpretasi}

Keterampilan interpretasi diartikan sebagai kemampuan yang menuntut siswa dapat memahami dan mengekspresikan makna dari berbagai macam pengalaman, situasi, dan data mencakup kemampuan mengkategorikan ataupun mengklarifikasi makna dari permasalahan yang dihadapi oleh siswa (Kowiyah, 2012). Pada tahap ini rata-rata kelas eksperimen memperoleh skor 87.36 dengan kategori sangat tinggi, sedangkan rata-rata kelas kontrol memperoleh skor 79.60 dengan kategori tinggi. Perbandingan hasil kemampuan berpikir kritis untuk setiap soal pada indikator interpretasi dapat dilihat pada Gambar 2.

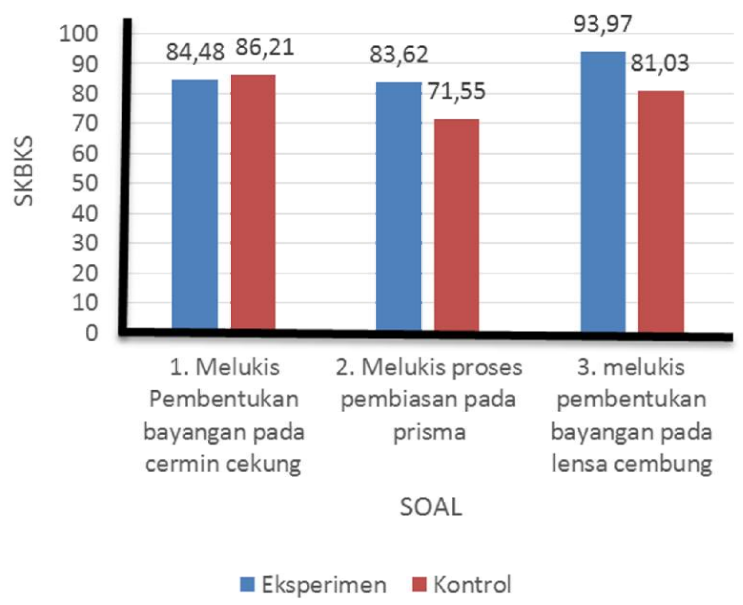

Gambar 2. Kemampuan berpikir kritis siswa pada indikator interpretasi.

Kemampuan berpikir kritis siswa indikator interpretasi untuk soal 2 dan 3 diperoleh skor kelas eksperimen lebih tinggi dibanding kelas kontrol dalam melukiskan proses pembiasan pada prisma dan pembentu kan bayangan pada lensa. hal ini disebabkan siswa kelas kontrol mengalami kesulitan dalam memahami dan mengekspresikan makna dari suatu masalah sehingga kemampuan dalam menginterpretasi persoalan kurang terlaksana dengan baik. Hal sebaliknya diperlihatkan pada soal 1 tentang melukiskan pembentukkan bayangan pada cermin cekung dengan perolehan skor kelas kontrol yang sedikit lebih baik dibanding kelas eksperimen. Hal ini menandakan bahwa keterampilan mengekspresikan makna pada sub pembahasan pemantulan kelas kontrol sudah dapat dikategorikan baik. Secara keseluruhan diperoleh kemampuan interpretasi kelas eksperimen lebih baik dibanding kelas kontrol.

\section{Keterampilan analisis}

Keterampilan analisis diartikan sebagai kemampuan yang menuntut siswa dapat mengidentifikasi hubungan antara pertanyaanpertanyaan, konsep-konsep, dan deskripsi untuk mengekspresikan penilaian, alasan, informasi dan opini meliputi pengujian data, pendeteksian argumen dan menganalisis argumen sebagai sub kecakapan dari kemampuan analisis (Kowiyah, 2012). Pada tahap ini rata-rata kelas eksperimen memperoleh skor 73.85 dengan kategori rendah, demikian pula dengan rata-rata kelas kontrol yang memperoleh skor 67.24 dengan kategori rendah. Perbandingan hasil kemampuan berpikir kritis untuk setiap soal pada indikator analisis dapat dilihat pada Gambar 3.

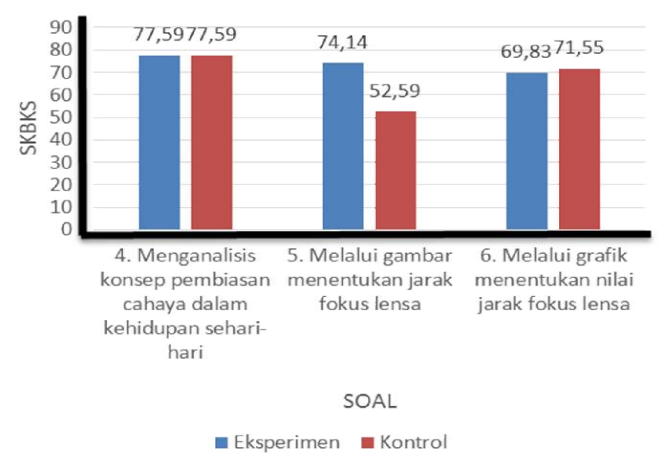

Gambar 3. Kemampuan berpikir kritis siswa pada indikator analisis.

Kemampuan berpikir kritis siswa indikator interpretasi untuk soal 5 diperoleh skor kelas eksperimen lebih tinggi dalam menentukan jarak fokus lensa dibanding kelas kontrol. hal ini disebabkan siswa kelas kontrol mengalami kesulitan dalam menganalisis hubungan antara representasi gambar yang disajikan dengan konsep yang berlaku untuk menentukan jarak fokus lensa. Sedangkan pada soal 6 skor kelas kontrol sedikit lebih tinggi dibanding kelas eksperimen, hal ini 
menandakan kelas kontrol sedikit lebih baik dalam menganalisis hubungan antara representasi grafik yang disajikan dengan konsep yang berlaku untuk menentukan jarak fokus lensa. Untuk soal 4 tentang menganalisis konsep pembiasan cahaya dalam kehidupan sehari-hari kedua kelas memperoleh skor yang sama.

Berdasarkan data diatas diperoleh bahwa keterampilan menganalisis siswa kelas eksperimen lebih tinggi dibanding kelas kontrol, hal ini disebabkan karena dalam pembelajaran discovery terbimbing disusun dari tahap demi tahap sampai akhirnya siswa dapat menemukan sendiri konsep yang dipelajari. Hal ini didukung oleh hasil penelitian Saido, et al. (2015) yang mengatakan bahwa salah satu pembelajaran yang efektif untuk mengembangkan kemampuan berpikir tingkat tinggi siswa adalah pembelajaran yang dapat mengaktifkan pengetahuan dan kemam-puan analisis siswa dengan memanfaatkan apa yang siswa tahu melalui pengajuan dan pengolahan hipotesis, guru dapat mendukung siswa dalam proses pembelajaran.

\section{Keterampilan evaluasi}

Keterampilan evaluasi diartikan sebagai kemampuan yang menuntut siswa dapat menaksir kredibilitas pernyataan atau deskripsi dari persepsi, pengalaman dan menaksir kekuatan logis dari hubungan inferensial baik itu berupa deskripsi maupun bentuk representasi lainnya (Kowiyah, 2012). Pada tahap ini rata-rata kelas eksperimen memperoleh skor 74.43 dengan kategori rendah, sedangkan rata-rata kelas kontrol memperoleh skor 63.51 dengan kategori sangat rendah.

Perbandingan hasil kemampuan berpikir kritis untuk setiap soal pada indikator evaluasi dapat dilihat pada Gambar 4. Berdasarkan analisis data dari ketiga soal pada kemampuan evaluasi siswa kelas eksperimen berada pada kategori rendah sedangkan pada kelas kontrol kemampuan evaluasi tergolong sangat rendah hal ini menunjukkan bahawa tingkat kemampuan evaluasi sebagai salah satu indikator berpikir kritis siswa masih tergolong rendah. Evaluasi dapat diartikan sebagai suatu kecakapan dalam membedakan antara argumen yang kuat dan relevan dengan argumen yang lemah dan tidak relevan. Kelas eksperimen memiliki kemampuan evaluasi yang sedikit lebih baik dibanding kelas kontrol setelah diterapkan model guided discovery learning. Hal ini dikarenakan dalam tahapan model pembelajaran guided discovery menurut kemendikbud (2013) ditekankan tentang tahapan verification sebagai proses siswa dalam melakukan pemeriksaan secara cermat untuk membuktikan benar atau tidaknya hipotesis yang ditetapkan tadi dengan temuan alternatif, dihubungkan dengan hasil data processing.

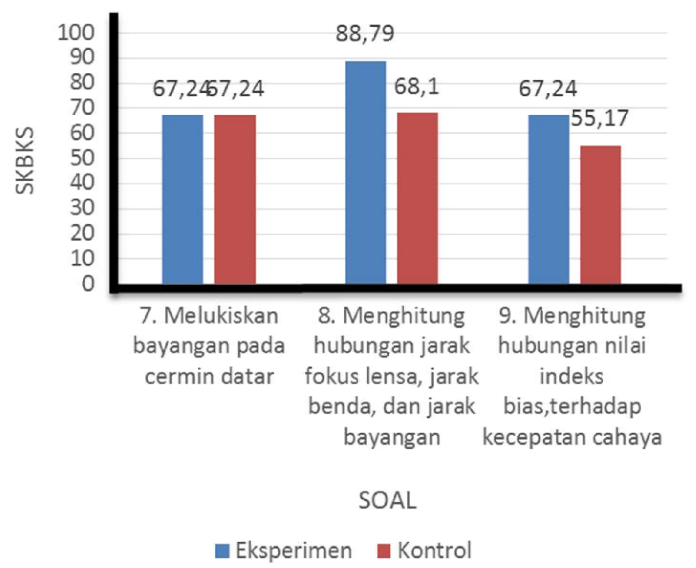

Gambar 4. Kemampuan berpikir kritis siswa pada indikator evaluasi.

\section{Keterampilan kesimpulan}

Keterampilan menyimpulkan diartikan sebagai kemampuan yang menuntut siswa dapat mengidentifikasi dan memperoleh unsurunsur yang diperlukan untuk membuat kesimpulan-kesimpulan yang logis, membuat dugaan dan hipotesis serta mempertimbangkan informasi yang relevan (Kowiyah, 2012). Pada tahap ini rata-rata kelas eksperimen memperoleh skor 80.75 dengan kategori tinggi, sedangkan rata-rata kelas kontrol memperoleh skor 73.56 dengan kategori rendah. Perbandingan hasil kemampuan berpikir kritis untuk setiap soal pada indikator kesimpulan dapat dilihat pada Gambar 5.

Kemampuan berpikir kritis siswa indikator kesimpulan untuk soal 11 dan 12 diperoleh skor kelas eksperimen lebih tinggi dibanding kelas kontrol dalam menyimpulkan hubungan jarak fokus terhadap kelengkungan cermin serta mengidentifikasi tingkat kerapatan suatu medium berdasarkan hukum 
pembiasan snellius. Kedua soal ini menandakan tingkat kemampuan menyimpul kan akan lebih maksimal ketika kelas diterapkan dengan model pembelajaran yang mampu merangsang peningkatan kemampuan menyimpulkan seperti model guided discovery learning dibanding model pembelajaran konvensional. Hal sebaliknya dapat dilihat pada soal 10 tentang menyimpulkan sifat bayangan pada cermin datar diperoleh kemampuan kelas kontrol sedikit lebih baik dibanding kelas eksperimen.

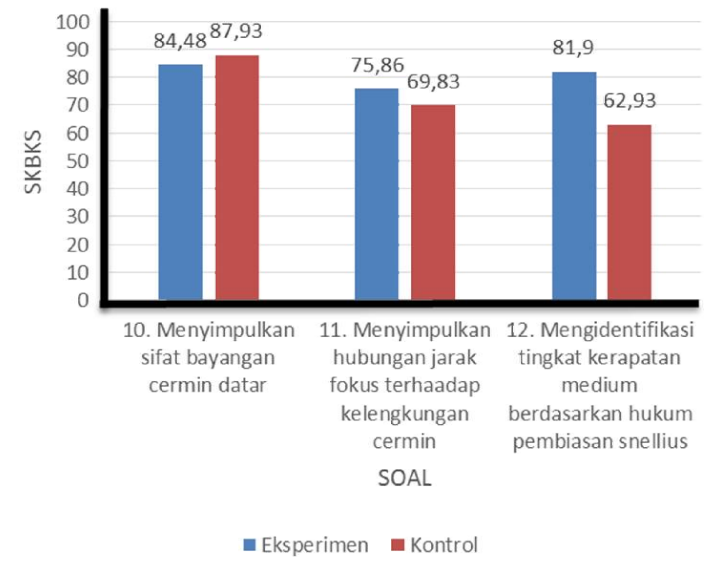

Gambar 5. Kemampuan berpikir kritis siswa pada indikator kesimpulan.

Berdasarkan analisis data dari ketiga soal pada kemampuan menyimpulkan siswa kelas eksperimen berada pada kategori yang lebih tinggi dibandingkan kelas kontrol. Hal ini membuktikan bahwa terdapat pengaruh positif setelah diterapkannya model pembelajaran guided discovery dalam meningkat kan keterampilan menyimpulkan sebagai salah satu indikator keterampilan berpikir kritis. Hal tersebut diperkuat dalam salah satu tahapan model guided discovery learning yang dimuat dalam Kemendikbud (2013) berupa tahap generalisasi/menarik kesimpulan yang diartikan sebagai proses menarik sebuah kesimpulan yang dapat dijadikan prinsip umum dan berlaku untuk semua kejadian atau masalah yang sama, dengan memperhatikan hasil verifikasi.

\section{Keterampilan penjelasan}

Keterampilan penjelasan diartikan sebagai kemampuan yang menuntut siswa mampu menyatakan hasil-hasil dari penalaran dan menjelaskan penalaran tersebut secara konseptual, metodologis dan kontekstual (Kowiyah, 2012). Pada tahap ini rata-rata kelas eksperimen memperoleh skor 75.86 dengan kategori tinggi, sedangkan rata-rata kelas kontrol memperoleh skor 68.68 dengan kategori rendah. Perbandingan hasil kemampuan berpikir kritis untuk setiap soal pada indikator penjelasan dapat dilihat pada Gambar 6.

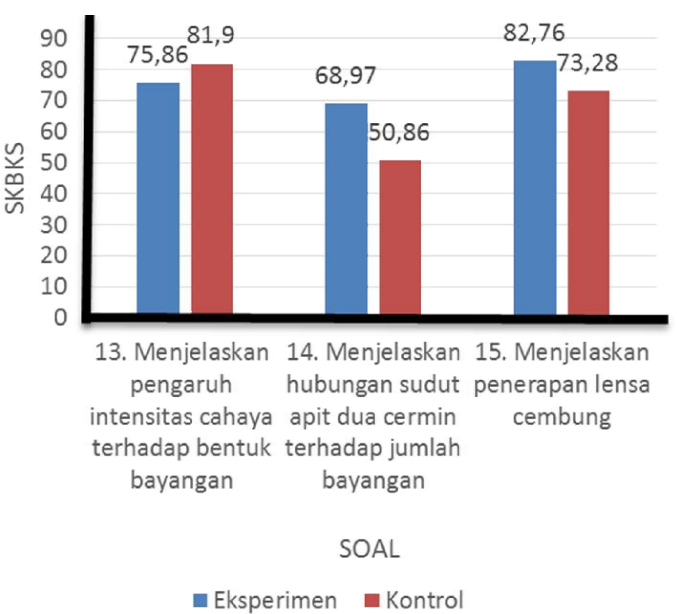

Gambar 6. Kemampuan berpikir kritis siswa pada indikator penjelasan.

Kemampuan berpikir kritis siswa indikator penjelasan untuk soal 11 dan 12 diperoleh skor kelas eksperimen lebih tinggi dibanding kelas kontrol, hal ini menunjukan terdapat pengaruh positif setelah diterapkannya model guided discovery learning terhadap kelas eksperimen. Sedangkan untuk soal 10 tentang menjelaskan pengaruh intensitas cahaya terhadap bentuk bayangan diperoleh skor rata-rata kelas kontrol lebih baik dibandingkan kelas eksperiment. Hal ini menandakan tingkat kemampuan penjelasan kelas kontrol untuk soal tersebut lebih baik dibanding kelas eksperimen, sehingga dapat di analisis yang menjadi salah satu penyebabnya adalah beberapa siswa yang mengalami kesulitan dalam menjelaskan konsep yang abstrak atau mengungkapkan hubungan antara konsep-konsep, yang tertulis atau lisan baik itu 
secara konseptual, metodologis dan kontekstual.

Berdasarkan analisis data dari ketiga soal pada keterampilan penjelasan siswa kelas eksperimen berada pada kategori tinggi sedangan kelas kontrol berada pada kategori rendah, hal ini menunjukkan terdapat perbedaan tingkat kemampuan berpikir kritis pada indikator penjelasan setelah diterapkannya model pembelajaran guided discovery learning pada kelas eksperimen dan model pembelajaran konvensional pada kelas kontrol. Menurut Ratumanan (2002) melalui pembelajaran penemuan terbimbing atau guided discovery learning, siswa belajar menemukan pola dalam situasi konkrit maupun abstrak, sehimgga siswa mampu menjelaskan dan meramalkan (extrapolate) informasi tambahan yang diberikan. Sehingga dapat diartikan kemampuan penjelasan siswa dapat tumbuh dan berkembang setelah melaui tahapan berupa Stimulasi atau Pemberian Rangsangan, identifikasi masalah, pengumpulan dan pengolahan data serta verivikasi dan generalisasi sebagai tahapan dalam pelaksanaan model pembelajaran guided discovery learning. Hal ini persis seperti yang ditulis oleh Kiki Yuliani \& Sahat saragih (2015) bahwa model pembelajaran guided discovery adalah model pembelajaran yang menyajikan masalah atau pertanyaan yang membuat siswa dapat berpikir, mengamati, membuat dugaan, menjelaskan dan menganalisis untuk menemu kan pengetahuan baru.

\section{Kesimpulan dan Saran}

Berdasarkan hasil keterampilan berfikir kritis siswa, maka dapat disimpulkan bahwa terdapat peningkatan kemampuan berpikir kritis setelah diterapkan mdel pembelajaran guided discovery learning sebesar 11.24\% dibanding dengan model pembelajaran konvensional.

Melalui kajian ini, dikomendasikan agar guru dapat menerapkan model pembelajaran guided discovery learning sebagai salah satu alternatif dalam pelaksanaan pembelajaran dalam menciptakan suasana yang membangun keterampilan berpikir kritis siswa. Bagi peneliti lain diharapkan penelitian ini berguna sebagai landasan untuk penelitian-penelitian yang relevan.

\section{Daftar Pustaka}

Angga Riantino \& Wasis, 2014. Pembelajaran Berorientasi Keterampilan Proses Sains dengan Model Guided Discovery untuk Meningkatkan Keterampilan Berpikir Kritis Siswa di Kelas XI SMA Negeri 1 Krian Sidoarjo. Jurnal Inovasi Pendidikan Fisika (JIPF), 03(01), 1924.

Candra Eko Purwanto, Sunyoto Eko Nugroho, \& Wiyanto, 2012. Penerapan Model Pembelajaran Guided Discovery pada Materi Pemantulan Cahaya untuk Meningkatkan Berpikir Kritis. Unnes Physics Education Journal, 01(1).

Kemendikbud, 2013. Model Pembelajaran Penemuan (Discovery Learning) $\mathrm{HO}-$ 2.2-3. Kemendikbud, Jakarta.

Kiki Yuliani \& Sahat Saragih, 2015. The Development of Learning Devices Based Guided Discovery Model to Improve Understanding Concept and Critical Thinking Mathematically Ability of Students at Islamic Junior High School of Medan. Journal of Education and Practice, 6(24), (Online).

Kowiyah, 2012. Kemampuan Berpikir Kritis. Jurnal Pendidikan Dasar, 3(5).

Permendikbud, 2016. Permendikbud RI No.22: Standar Proses Pendidikan Dasar Dan Menengah. BNSP, Jakarta.

Ratumanan, 2002. Model Pembelajaran Menciptakan Proses Belajar Mengajar yang Efektif. Bumi Aksara, Jakarta.

Rusman, 2012. Model-model Pembelajaran. Rajagrafindo Persada, Jakarta.

Saido, Gulistan, A.M., Siraj, Saedah., Nordin, A.B., \& Omed, S.A. 2015. Teaching Strategies for Promoting Higher Order Thinking Skills: A Case of Secondary Science Teachers. Malaysian Online Journal of Education Management (MOJEM), 3, (4), 16-30, E-ISSN:22894489. Malaysia.

Setyosari, Punaji, 2010. Interaksi dan Motivasi Belajar Mengajar. Rajawali, Jakarta. 
Suyono \& Hariyanto, 2011. Belajar dan Pembelajaran. PT Remaja Rosdakarya Offset, Bandung.
Wowo Sunaryo Kuswana, 2012. Taksonomi Kognitif Perkembangan Ragam Berpikir. PT. Remaja Rosdakarya, Bandung. 